\title{
CATECHOLAMINES AND STRESS
}

\author{
Miklós PALKOVITS \\ Human Brain Tissue Bank and Laboratory, Semmelweis University, Budapesł
}

\begin{abstract}
A brief survey is offering of debates on two long-standing questions in stress studies and theories: 1) question of stress nonspecificity (i.e. homo- or heterogeneity in stress responses), and 2) what is the functional role of central catecholamines in stress mechanisms, especially in stress signaltransduction and in the realization of stress responses.
\end{abstract}

\author{
A KATECHOLAMINOK ÉS A STRESSZ \\ Palkovits $M, M D$, DsC \\ Ideggyogy Sz 2014;67(3-4):89-93.
}

Keywords: stress, ascending catecholamine system, descending catecholamine system, hypothalamo-pituitary-adrenal (HPA) axis

\begin{abstract}
A közlemény rövid áttekintést ad a stresszvizsgálatok és stresszelméletek két régóta vitatott kérdéséról: 1. a stressz, illetve a stresszre adott válasz alapjában véve specifikusnak vagy heterogénnek tekinthető-e, és 2 . mi a funkcionális szerepe és jelentösége a központi idegrendszeri katecholaminneuronoknak a stressz-szignál továbbításában és a stresszre adott válasz realizálódásában?
\end{abstract}

Kulcsszavak: stressz, ascendáló katecholamin-rendszer, descendáló katecholamin rendszer, hypothalamus-hypophysis-mellékvese (HPA-) tengely

\section{Correspondence: Miklós PALKOVITS, MD, DSc, Human Brain Tissue Bank and Laboratory, Semmelweis University; H-1094 Budapest, Túzoltó u. 58. \\ Phone: +36-1-216-0488, fax number: +36-1-218-1612 \\ E-mail: palkovits.miklos@med.semmelweis-univ.hu}

Érkezett: 2013. november 20. Elfogadva: 2014. február 10.

\section{www.elitmed.hu}

$\mathrm{D}$ uring the first half of the $20^{\text {th }}$ century, within ten years, two theories were introduced about external and internal factors that may influence the body homeostasis. One of the theories was introduced by Cannon ${ }^{1}$ who used the term fight-orflight, the other theory was published by Selye $e^{2}$ who called this phenomenon stress. The basic idea of these two theories was almost the same: the organism may react somehow to the extremely variable stimuli that arise either from outside or inside the body. Their explanations on the mechanisms of responses however, were completely different. Cannon underlined the role of the sympathetic nervous system, the adreno-medullary catecholamines, while Selye preferred the anterior pituitary-adrenocortical system that produces corticosteroids. Selye considered the adrenal cortex to be the organ of integration during stress.

Selye's view on catecholamines in the stress was "minimal". Although, he recognized from Cannon's work that stressors elicit neuronally mediated sympatho-adrenal responses, he never incorporated this finding properly in his stress theories.

Cannon was the first to introduce the term "homeostasis". He concentrated on the role of the adrenal medulla in fight-or-flight reaction ${ }^{1}$ (this phrase was used for all type of reactions that may change body homeostasis before the term stress has been introduced by Selye in $1936^{2}$ ), Selye turned to the adrenal cortex, as a key participant of the anterior pituitary-adrenocortical (HPA) axis. Thus, Selye's studies were focused to corticosterone with relatively minor respect to adrenaline or noradrenaline. Cannon never used the term "stress".

The first description of adrenaline ${ }^{3}$ (this is a milestone study. Unfortunately, the contribution of Kálmán Lissák in the first description of brain 
adrenaline neurons has been almost forgotten), noradrenaline $\mathrm{e}^{4}$ in nerve fibers, and their present and activation in the brain ${ }^{5}$, as well as their inactivation by both neuronal reuptake and/or by enzymatic degradation ${ }^{6,7}$ clearly demonstrated the functional significance of these substances in neuronal mechanisms that basically influence the body homeostasis. Selye recognized these studies, he admired the work of Axelrod. Although, he did not spent too much time with working on catecholamines, had high respect to Julius's work. Fair, almost friendly connection existed between these two giants. Axelrod never performed studies on any kind of stress but he favored Selye's idea. I remember to his short comment about Selye: "He introduced something very important in science that always existed in life. He is fantastic, a genius, but somewhat he is a very complicated man."

The obvious question has been raised: Why did Selye make a relatively little attention on brainborn adrenaline and noradrenaline in stress? It is most probably that the lack of routine techniques for measuring micro quantities of released catecholamines from the sympathoneural or adrenomedullary systems that time, Selye whose mind and working attitude preferred the exact, visible and measurable parameters in his studies, did not consider central catecholamines as major factors in the stress mechanism, at least not that time when he introduced his stress story.

\section{Stress specificity or nonspecificity}

Hans Selye was an extraordinarily active researcher who was able to brilliantly popularize his theory as a medical and scientific idea. In 1936, when Selye formulated his stress definition, he named three objective indicators that could be recognized no matter how stress was produced: the activation of the HPA axis, involution in the thymicolymphatic system, and gastrointestinal peptidergic ulcer. This statement became later the "stress nonspecificity" or "stress homogeneity" theory. This dogma be came extraordinarily popular, it is hard to find any similar in the neuroscience.

When Selye's doctrine was formulated, only three objective indicators existed that could be recognized no matter how stress was produced. Later more and more data and observations have been published indicating the existence of a variety type of stressors with different targets and different effects on the homeostasis. For review, see Kvetnansky et al., 20098 and Pacak and Palkovits, $2001^{9}$. In 1998, the Selye's doctrine of nonspecifici- ty underwent systematic experimental testing, which failed to confirm it ${ }^{10}$.

Based on measurements of plasma levels of adrenaline, noradrenaline, catecholamine precursors, and metabolites in stress, it is generally accepted that sympatho-adrenomedullary system and sympatho-neuronal system (HPA axis) are specifically, and somewhat independently, activated by different stressors. Exposures to cold evoke a selective activation of sympatho-neuronal system, as indicated by elevated plasma noradrenaline levels, whereas insulin-induced glucoprivation or emotional stressors activate sympatho-adrenomedullary system, as indicated by plasma adrenaline responses. Other stressors, such as restraint or formalin-induced pain, activate both systems. Immobilization represents a severe stress that elicits an extremely large increase in plasma adrenaline and noradrenaline. Results from a variety of studies indicate that not only the peripheral but also the central catecholamine system and the hypothalamic-pituitary-adrenal (HPA) axis respond specifically to different stressful stimuli. An intact HPA axis is essential for the activity of PNMT, the enzyme responsible for adrenaline synthesis in the adrenal medulla. Thus, depending on the nature and the target sites of various stressors, the two systems may be regulated by different central pathways ${ }^{10,11}$.

One point, however, should be mentioned. Selye himself treated and explained his doctrine of nonspecificity different way in 1936 than in 1980 . He wrote in 1980: ,Stress is nonspecific. This does not mean that all stress situations are identical because stress is never seen in isolation. You cannot produce stress in pure form without using a stressor, and the latter necessarily always has specific effects $^{12}$." ... "The fact that all stress situations are apparently different does not nullify their nonspecificity. ... This is explained by two circumstances: (A) the stressor is always accompanied by specific side effects; (B) both internal and external predisposing factors modify the response ${ }^{12}$."

\section{Brain catecholamines in stress}

To maintain homeostasis, the sympathetic nervous system responds to several different types of sensory inputs. Brain adrenergic and noradrenergic neurons are involved in the central processing of stress responses. For review, see Kvetnansky et al., $2009^{8}$ and Pacak and Palkovits, 20019. Activation of the sympathetic nervous system leads to the outflow of adrenaline from the adrenal medulla and outflow of noradrenaline from the varicosities of the sympa- 


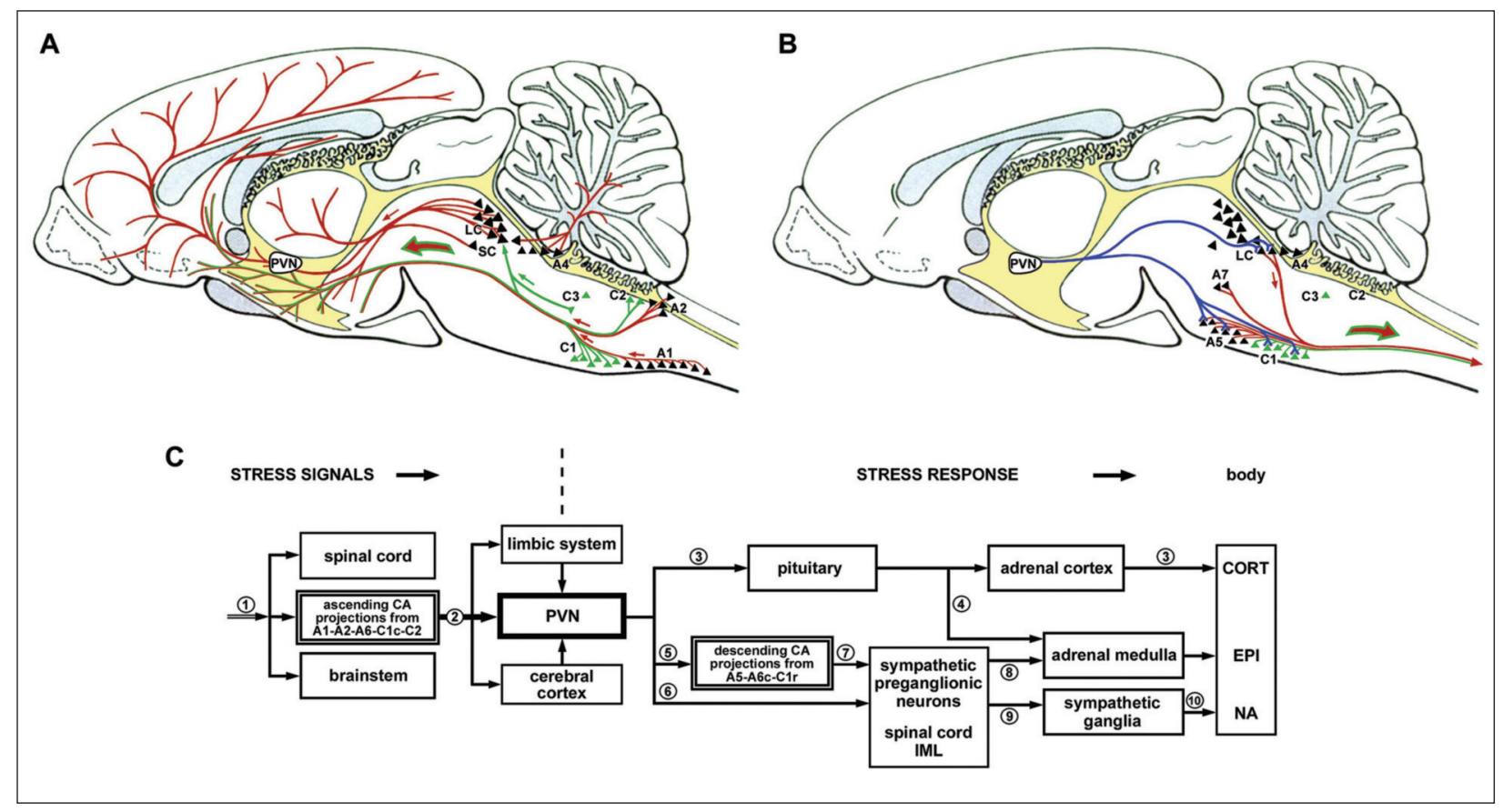

Figure 1. Stress signal routes and pathway in stress response. Figure $\mathbf{A}$ and $\mathbf{B}$ : red-noradrenaline projections; green - adrenaline projections. Figure B: blue - paraventricular projections to the locus coeruleus and A5 cell group. Figure C: 1. stressful stimuli; 2. projections to higher brain centers - ascending catecholamine projections from the lower brainstem; 3. hypothalamo-anterior pituitary-adrenal cortex axis (HPA axis); 4. anterior pituitaryadrenomedullary connection (ACTH action on the adrenal medulla); 5. PVN projections to descending CA-projection neurons (to premotor sympathetic neurons); 6. direct PVN projection to spinal preganglionic sympathetic neurons; 7. projections of premotor sympathetic neurons to the spinal preganglionic sympathetic neurons (descending catecholamine pathway); 8. sympathetic preganglionic fibers to the adrenal medulla; 9. preganglionic sympathetic fibers; 10. postganglionic sympathetic fibers

A1-A7: A1-A7 noradrenaline cell groups (A6c - caudal portion of the locus coeruleus); C1-C3: C1-C3 adrenaline cell groups (C1c - caudal, C1r - rostral portions of $\mathrm{C} 1$ cell group); CA: catecholamines; CORT: corticosterone; EPI: adrenaline; LC: locus coeruleus; NA: noradrenaline; PVN: paraventricular nucleus; SC: subcoeruleus area

thetic postganglionic axons. In response to acute stressor, large amounts of adrenaline and noradrenaline are released. Depending on the nature, the intensity, the duration of stressful stimuli, levels of adrenaline and noradrenaline in the plasma may increase from ten to several hundred folds.

The brain catecholamine system can be divided into two major parts, according to their projections and innervation patterns. One group, the ascending central catecholamine system constituted by the $\mathrm{A} 1, \mathrm{~A} 2$, noradrenaline, $\mathrm{C} 1$ caudal and $\mathrm{C} 2$ adrenaline cell groups, and the major part of the locus coeruleus in the lower brainstem innervates the forebrain, the hypothalamus including the paraventricular nucleus (Figure 1A, 1C). Axons from these neurons receive direct somato- and viscerosensory inputs. Their activation is stressor-specific, these fibers represent a part of the stress-signal routes. That constitute a part of the ascending reticular activating system innervate - among many other regions - the HPA axis. The paraventricular nucle- us, as the central part of the HPA axis receives, beside catecholamines several neuronal inputs from limbic and cortical brain areas and humoral inputs, i.e. CRH, ACTH or corticosteroid feedback (Figure 2.).

High number of noradrenaline (A5, A7, caudal locus coeruleus) and adrenaline (C1) neurons constitute the descending central catecholamine system, that project to the sympathetic preganglionic neurons in the intermediolateral cell column of the thoracic spinal cord (Figure 1B and Figure 3.). Neurons of this descending system receive neuronal input from the paraventricular nucleus (Figure 3.). Neurons in the paraventricular nucleus have also direct projections to the sympathetic preganglionic neurons (Figure 3.), i.e. they may act directly, as sympathetic premotor neurons.

The sympathoadrenal system is composed of sympathetic preganglionic neurons in the IML cell column and the chromaffin cells of the adrenal medulla (Figure 3.). The activation of sympathetic 


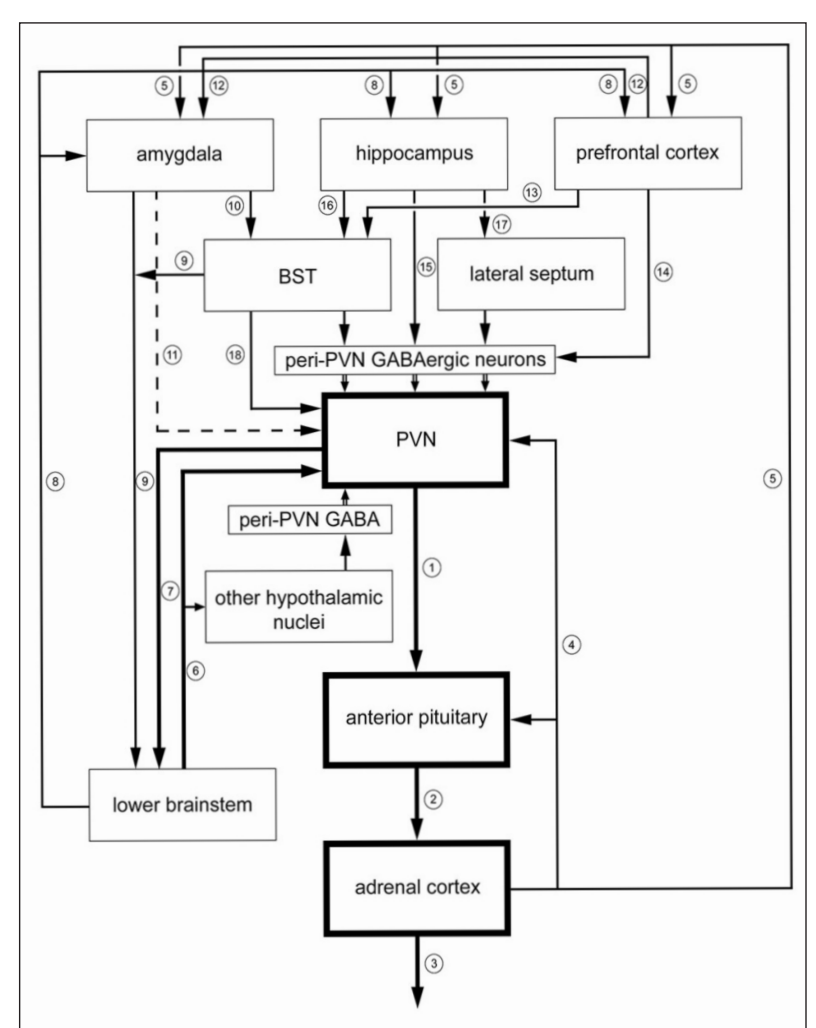

Figure 2. Neuronal connections of the paraventricular nucleus (PVN). 1-3. Hypothalamo-anterior pituitaryadrenal medullary (HPA) axis; 4. glucocorticoid feedback; 5. corticoids in the circulation; 6. ascending catecholamine projections from brainstem NA and EPI neurons to the PVN; 7. PVN projections to premotor sympathetic preganglionic neurons (locus coeruleus, A5 NA and C1 EPI cell groups) in the lower brainstem; 8. ascending CA projections from the lower brainstem to limbic and cortical areas; 9. central amygdala $+B S T$ projections to the lower brainstem; 10. stria terminalis; 11. direct amygdala projections to the PVN; 12. prefrontal projections to the amygdala; 13. prefrontal projections to the BST; 14. prefrontal projections to periPVN GABAerg neurons; 15. hippocampal projections to peri-PVN GABAerg neurons; 16. hippocampal projections to the BST; 17. fimbria/fornix; 18. direct BST projections to the PVN; unlabeled arrows - projections to peri-PVN GABAerg neurons; unlabeled double arrows peri-PVN GABAerg projections to the PVN

BST: bed nucleus of the stria terminalis; CA: catecholamine; EPI: adrenaline; NA: noradrenaline

preganglionic neurons is controlled by distinct neuronal cell groups, called premotor sympathetic cell groups, probably by distinct neurotransmitters. The premotor sympathetic neurons used to be classified as catecholaminergic and non-catecholaminergic.

Although, most of the forebrain regions, including those are classified into the "limbic system"

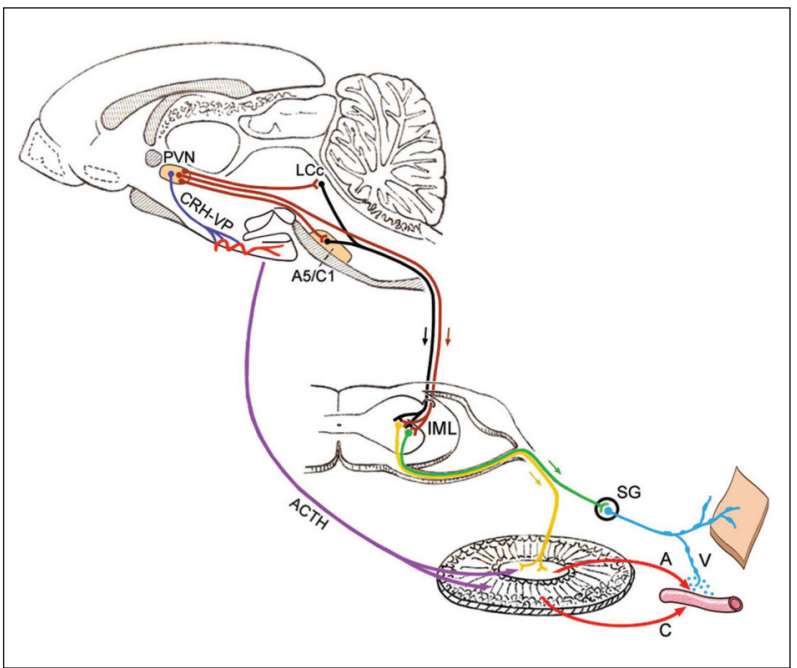

Figure 3. Sympathetic premotor projections in the sympatho-adrenal and sympatho-neuronal system ${ }^{11}$ with modifications. Blue-red-violet: HPA axis; red: paraventricular projections to brainstem sympathetic premotor neurons and direct projections to sympathetic preganglionic neurons; black: locus coeruleus and A5 catecholamine projections to sympathetic preganglionic neurons; yellow: sympatho-adrenal system - preganglion projections to the adrenal medulla; green: preganglionic sympathetic fibers; blue: postganglionic sympathetic fibers; red: release of noradrenaline and adrenaline from the adrenal gland

A: adrenaline; A5: A5 catecholamine cell group; C: corticosterone; C1: $\mathrm{C} 1$ adrenaline cell group; $\mathrm{CRH}$ : corticotropin-releasing hormone; IML: intermediolateral cell column (with sympathetic preganglionic neurons); LCc: caudal cell group in the locus coeruleus; PVN: paraventricular nucleus; SG: sympathetic ganglion; V: varicosities on noradrenergic axons; VP: vasopressin

control the sympathetic outflow, they do not directly innervate spinal preganglionic sympathetic neurons. They exert their actions through by way of the hypothalamus, actually through paraventricular neurons (PVN). Cortical projections to the PVN mainly arise in the prefrontal cortex and the anterior cingulate cortex. The hippocampus and the amygdala reach the PVN through the bed nucleus of the stria terminalis. The paraventricular premotor sympathetic neurons are peptidergic.

For detailed description of the sympathoadrenal system, as neuronal arm of the stress response, please see the Encyclopedia of Neuroscience. ${ }^{11}$

Just one further note: Introducing new image analyzing techniques, especially the functional magnetic resonance imaging one, brought new possibilities in stress studies. These techniques provide us unique information about the activity of the "living" human brain.

To complete this brief overview, may cite two 
sentences from Selye ${ }^{12}$ which express his objectives in stress studies and thinking about stress and life:

1) "From laboratory and clinical work on stress we have tried to arrive at a code of ethics founded, not on the traditions of our society, not inspiration or blind faith in the infallibility of the teachings of any particular prophet, or religious leader or manmade political doctrine, but on the scientifically verifiable laws of Nature that govern the body's reactions in maintaining homeostasis and living in satisfying equilibrium with its surroundings."

2) "Find your own natural stress level and run toward what you accept as your own goal. ...

\section{REFERENCES}

1. Cannon WB. Organization for physiological homeostasis. Physiol Rev 1929;9:399-431.

2. Selye $H$. A syndrome produced by diverse nocious agents. Nature 1936;138:32.

3. Cannon WB, Lissak K. Evidence for adrenaline in adrenergic neurons. Am J Physiol 1939;125:765-77.

4. von Euler US. A specific sympathomimetic ergone in adrenergic nerve fibres (sympathin) and its relations to adrenaline and noradrenaline. Acta Physiol Scand 1946;12:73-96.

5. Vogt M. Norepinephrine and epinephrine in the central nervous system. Pharmacol Rev 1954;6:31-2.

6. Axelrod J. O-methylation of (epinephrine and other catecholamines) catecholamines in vitro and in vivo. Science 1957;126:400-1.

7. Axelrod J, Weil-Malherbe H, Tomchick R. The physiological disposition of H3-epinephrine and its metabolite metanephrine. J Pharmacol Exp Ther 1959;127:251-6.
Granted, this is difficult and takes much time, but too many people suffer all their lives because they are too conservative to risk a radical change and break with tradition."

\section{ACKNOWLEDGEMENT}

This paper is based on the lecture untitled The Axelrod-Selye connection: Catecholamines and steroids presented in the Selye-Szimpózium 2013 at the Hungarian Academy of Sciences.

The author is grateful for Magdolna ToronyayKasztner for her technical help to complete both the presented and written materials.
8. Kvetnansky R, Sabban EL, Palkovits M. Catecholaminergic systems in stress: structural and molecular genetic approaches. Physiol Rev 2009;89:535-606.

9. Pacak K, Palkovits M. Stressor specificity of central neuroendocrine responses: implications for stress-related disorders. Endocr Rev 2001;22:502-48.

10. Pacak K, Palkovits M, Yadid G, Kvetnansky R, Kopin IJ, Goldstein DS. Heterogeneous neurochemical responses to different stressors: a test of Selye's doctrine of nonspecificity. Am J Physiol Regul Integr Comp Physiol 1998;275:R1247-R1255.

11. Palkovits $M$. Sympathoadrenal system: Neural arm of the stress response. In: Squire LR (ed.). Encyclopedia of Neuroscience. Oxford: Academic Press; 2009. p. 679-84.

12. Selye's Guide to Stress Research. Selye H (ed.). New York: Van Nostrand Reinhold; 1980. 